\title{
Rethinking the Nation in the Chilean and Australian Bicentenaries
}

\author{
Irene Strodthoff ${ }^{1}$
}

\section{Abstract}

Bicentenaries, as created and chosen historical moments, can be considered a space for reflection on the achievements and challenges of a nation and its collective project in a setting of contestations. This article argues that rethinking the nation and articulating the discourse of identity both in Chile and in Australia have become contentious within the respective bicentenaries because of issues of exclusion and inclusion in which the 'white' settlement associated winners with 'white' people and the defeated with indigenous peoples. Both located in the southern hemisphere, Australia and Chile share a past as former British and Spanish settler colonies, respectively, and they have therefore shown certain socio-historical similarities in regard to the nation-building project against the original indigenous population that have fractured the discourse of the nation.

\section{Introduction}

Bicentenaries are an appropriate framework within which to examine the nation as an unfinished project and as a unique experiment that attempts to give cohesion to its members. These commemorations challenge the nation with reference to tradition and continuity as well as certain ambiguities of mutable national identity in the midst of inevitable cultural tensions between the present and the past in a society that tends to be heterogeneous, controversial and the object of continuous debate. Usually conceived as commemorations of the beginning of the nation-building project, bicentenaries can also provide a suitable framework within which to discuss the achievements and challenges of a nation and its collective undertaking in a setting of contestations. To understand the nation's capacity to integrate and articulate itself, it is necessary to examine these commemorations in terms of inclusion and exclusion processes as well as multifarious contradictions.

1 Not to be cited without the permission of the author. Email: <istr9460@uni.sydney.edu.au> 
This article argues that rethinking the nation and articulating the discourse of identity both in Chile and in Australia have become contentious within the respective bicentenaries because of issues of exclusion and inclusion originating from the idea of imagining a 'white' nation, where the 'white' settlement associated winners with 'white' people and the defeated with indigenous peoples. Despite the fact that Latin América is not usually described as a 'whitesettler' country, it shares common features with the English expression. ${ }^{2}$ This article aims to compare and deconstruct the discourse of the nation in the context of the Australian bicentenary in January 1988 and the Chilean bicentenary in September 2010.

This article situates the analysis within the ideas of nation and identity according to Benedict Anderson ${ }^{3}$ and Jorge Larraín. ${ }^{4}$ Anderson suggests that the nation is imagined as a community because, despite the fact that most members will never know each other, they still share a sense of communion in their minds. ${ }^{5}$ Larraín understands the idea of identity as a social construction that entails the identification of individuals with shared social categories, such as nationality or ethnicity, and consequently, he argues, 'all personal identities are rooted in collective contexts culturally determined' ${ }^{6}$ Therefore, if the sense of belonging to a group is not strong enough, the notion of identity might weaken.

Australia and Chile consider different historical starting points to commemorate their respective bicentenaries and, owing to their distinct social, cultural and historical processes, they have approached these chosen moments in a unique way. Along with Argentina, Colombia, Mexico and Venezuela, Chile celebrates the commencement of the independence process from Spain (18 September 1810) - a time when the nation-building process began to emerge. On the other hand, Australia's two-hundredth anniversary is based on the arrival in 1788 of the First Fleet - 11 ships transporting convicts and crew-and the starting point of British colonisation (26 January, officially known as Australia Day). ${ }^{7}$ In contradistinction with Chile, the Australian nation-building process began 90 years later, when the existing six British colonies became states and Federation was finally proclaimed in Australia in 1901. Both located in the southern hemisphere, Australia and Chile share a past as former British and Spanish

2 The use of the stress (acento) on América is based on the original sense of the word in Spanish - 'América con acento' - described by Cherríe Moraga in 'Art in América con acento', in D. Taylor and J. Villegas (eds) 1994, Negotiating Performance: Gender, sexuality, and theatricality in Latin/o America, Duke University Press, Durham, NC.

3 Anderson, B. 2006, Imagined Communities: Reflections on the origin and spread of nationalism, Verso, London.

4 Larraín, J. 2000, Identity and Modernity in Latin America, Polity Press, Cambridge.

5 Anderson, Imagined Communities, p. 6.

6 Larraín, Identity and Modernity in Latin America, p. 24.

7 The Australian states and territories started to use the name Australia Day in 1935, but it was only in 1994 that they began to celebrate it as a public holiday. 
settler colonies, respectively, and they have therefore shown certain sociohistorical similarities in regard to the nation-building project against the original indigenous population (Aborigines and mainly Mapuches, respectively). ${ }^{8}$

Despite remaining invisible for a long time, this situation began to change towards certain gestures of inclusion and rhetorical recognition with the increasing social mobilisation of the indigenous population both in Australia and in Chile in the context of more recent collective historical moments. While the Australian bicentenary was the appropriate framework for a sudden re-emergence of the Indigenous discourse, the advent of 500 years since the arrival of the Spaniards in the Americas in 1992 became the 'necessary and appropriate context for the emergence of new indigenous identities, new discourses on ethnicity, new organisations and new movements' ${ }^{9}$ The occurrence of indigenous movements in Latin América as well as the arrival of democracy in Chile in 1990 opened up a space for the re-emergence of the Mapuches within the imagined nation in terms of cultural identity and land rights in the lead-up to the Chilean bicentenary. ${ }^{10}$

First, this article will analyse the nation-building process of both countries in a setting of exclusion and inclusion. Second, it will examine the complexities challenging the nation within a selected historical moment such as the bicentenary.

\section{Nation Building: A non-negotiated project}

Regarding the objective of becoming European colonies, the appropriation of land was the first confrontational issue between settlers/conquerors and indigenous peoples. Both the British and the Spanish — despite this being a more British notion - understood this appropriation in terms of 'terra nullius', where 'unoccupied land remained the common property of mankind, until being put

8 When British colonists arrived in 1788 in Australia, there were about 300000 Aboriginal Australians divided among 500 tribes, each with their own dialect and culture: Broome, R. 1994, Aboriginal Australians: Black response to white dominance, 1788-1980, (Second edition), Allen \& Unwin, St Leonards, NSW, p. 10. According to the Australian Bureau of Statistics (2008), the estimated resident Indigenous population is about 517000 people, or 2.5 per cent of the total Australian population. When the Spanish conquerors started to arrive in Chile in 1536, the population of Mapuches - one group of the original indigenous inhabitants of central and southern Chile as well as southern Argentina - was nearly one million people: Bengoa, J. 1996, Historia del pueblo Mapuche: Siglo XIX y XX, (Fifth edition), Ediciones Sur, Santiago, p.15.La emergencia indígena en América latina, Fondo de Cultura Económica, Santiago, p. 15. According to the most recent census (2002), 4.6 per cent of the Chilean population (692 192 people) consider themselves to be members of an ethnic group. While the Mapuches represent 87.4 per cent of that total, other ethnic groups, in descending order, are the Aimara, Atacameño, Quechua, Rapa Nui, Colla, Alacalufe and Yámana. Despite these being distinct groups, I use the word Mapuches as an umbrella term since they are the most numerous indigenous population in Chile.

9 Bengoa, La emergencia indigena en América latina, [Author's translation], p. 95.

10 The Chilean bicentenary took place in the midst of a hunger strike led by 34 Mapuches, who were seeking the abolishment of a polemic anti-terrorist law. 
to use'. ${ }^{11}$ The European explorers believed that land could be freely taken if it was either unpopulated or inhabited by people who did not practice agriculture or change the land by constructing towns. ${ }^{12}$ Since land was the major object of occupation and the basis for setting up European societies, the ties between explorers and Aborigines (Australian Indigenous people) as well as Mapuches were developed in a binary and negative articulation of invaders and the invaded, and enemies as well as rivals. ${ }^{13}$ Both in Australia and in Chile, the appropriation of land by British explorers and Spanish conquerors was the origin of clashes with the native population and caused a negative articulation - a relationship based on dispossession and loss.

As appropriation of land did not involve any negotiation with the indigenous populations, the historical consequences of this moment of loss led to a context of exclusion. In Australia, Britain's declaration of ownership over the continent excluded any treaty with the Aborigines and ignored any acknowledgment of native title. ${ }^{14}$ In Chile, as in other territories in Latin América, Spanish conquerors were determined - more than the appropriation of land as an isolated issueto subjugate and expel the indigenous inhabitants. ${ }^{15}$ Therefore, the ideas of subjugation and expulsion brought historical tensions to the nation-building project and the discourse of the nation.

These historical tensions originated not only because of land, but also on account of the purpose of settlers and conquistadors to impose their own projects. Australia was seen as an 'imperial artefact' - a result of the expansion of the British Empire with superstructures imposed from above that displaced Indigenous people. ${ }^{16}$ In this context, the Indigenous people were 'almost completely peripheral' to the colonisation project. ${ }^{17}$ Chile, as other countries in Latin América, was the result of a process of conquest, which imposed relations of domination and placed some in a 'natural situation of inferiority to the others' ${ }^{18}$ This relationship, based on imposition, both in Australia and in Chile has framed the nation-building project as a hegemonic narration with fractures where the original views became subordinated.

On account of this hegemonic narration and the perception of the nation as a 'white' project, the Aborigines and the Mapuches did not fit within the Australian

11 Elliott, J. 2006, Empires of the Atlantic World, Yale University Press, New Haven, Conn., p. 30.

12 Wolfe, P. 1999, Settler Colonialism and the Transformation of Anthropology, Cassell, London, p. 26.

13 In mapudungun, the Mapuche language, 'mapu' means earth and 'che', people.

14 Broome, Aboriginal Australians, p. 26.

15 Elliott, Empires of the Atlantic World, p. 30.

16 Beilharz, P. and Cox, L. 2006, 'Nations and nationalism in Australia and New Zealand', in G. Delanty and K. Kumar, The SAGE Handbook of Nations and Nationalism, Sage, London, p. 555.

17 Moran, A. 2005, Australia: Nation, belonging and globalization, Routledge, New York, p. 134.

18 Quijano, A. 2000, 'Coloniality of power, Eurocentrism, and Latin America', Nepantla: Views from South, vol. 1, no. 3, p. 533. 
and the Chilean nation-building projects, respectively. They were seen as a different group - a threat to the objective of shaping national homogeneity. Aborigines were automatically excluded when Australia proclaimed the Federation in 1901 and imagined its destiny as a 'white' nation. Australian Aborigines did not fit into the label of 'white Australia'. They were placed in the category of 'aliens' - a non-white classification. ${ }^{19}$ In Anthony Moran's view, this attempt by an emergent state to build an 'ethnically homogenous nation' provoked a situation in which Indigenous peoples were kept out of the nation and had nowhere else to go. ${ }^{20}$ In Chile, when the state proclaimed its sovereignty over the whole territory to build the nation during the second half of the nineteenth century, the Mapuches began to be excluded by a political and intellectual class that felt 'awkward' with their presence; they came to be seen as enemies of civilisation and a nuisance for progress. ${ }^{21}$ The attempt of forging a homogenised 'white' nation both in Chile and in Australia excluded the original indigenous population because they were not suited for this purpose.

In this objective of attaining national homogeneity in Australia, the Aborigines were supposed to disappear, so they were sent to remote places, or assimilated through explicit policies of intermarriage and cultural absorption, which, on the surface, appeared to be inclusion, but in reality tended to negate them. The invisibility of the Aborigines was driven to extremes and only in 1967, by a referendum, were they first recognised as citizens and counted as people. ${ }^{22}$ Assimilation was built on notions of egalitarianism, albeit those intentions were structured by a 'settler-colonial relationship that assumed the disappearance of Aboriginality'. ${ }^{23}$ Aborigines were seen as an opposite to the hegemonic European discourse of settlement in which there was no room for difference. Absorption included a 'naïve social engineering' intended to change Aborigines into Europeans with black skins. ${ }^{24}$ Some governments, as in Western Australia and the Northern Territory, applied breeding policies through 'interracial' marriages during the 1930s and 1940s that evolved into cultural assimilation, whereby the Aborigines would replace their old ways with those of whites. ${ }^{25}$ Furthermore, these policies included taking Aboriginal children away from their parents to grow up in 'white' foster homes. These children are known

\footnotetext{
19 Moran, Australia, p. 140.

20 Moran, A. 2005, 'White Australia, settler nationalism and Aboriginal assimilation', Australian Journal of Politics and History, vol. 51, no. 2, p. 172.

21 Pinto, J. 2003, La formación del estado y la nación, y el pueblo Mapuche: De la inclusión a la exclusión, (Second edition), Ediciones de la Dirección de Bibliotecas, Archivos y Museos, Santiago, [Author's translation], p. 119.

22 Pettman, J. 1988, 'Learning about power and powerlessness: Aborigines and white Australia's bicentenary', Race \& Class, vol. XXIX, no. 3, p. 75.

23 Moran, 'White Australia, settler nationalism and Aboriginal assimilation', p. 180.

24 Broome, Aboriginal Australians, p. 171.

25 Moran, Australia, p. 142.
} 
as the 'Stolen Generations'. ${ }^{26}$ Through explicit policies of cultural absorption and imagining Aboriginal children as 'white' in Australia, the visibility of the Indigenous peoples was deliberatively negated and suppressed.

Similarly in Chile - albeit not through explicit interracial policies - the Mapuches were assimilated and negated through the mestizaje, the rather spontaneous mix that occurred between Spaniards and the indigenous population. Mestizaje simultaneously represents inclusion and exclusion within the nation-building project. It is discursively constructed around the symbolics of the original and certain future homogeneity in a continuous recreation; it reflects tension between equality and inequality, sameness and hierarchy. ${ }^{27}$ While inclusion is brought about by national homogenisation, exclusion is shaped through differentiation and racism. ${ }^{28}$ In Chile, since the Spanish conquerors did not bring women to the territory, mestizaje began almost on their arrival and became highly prevalent during the sixteenth century and over those that followed. Rather than an integrated mix, the Mapuches remained separate from this process. In this tension between sameness and difference, the Mapuches remained as those defined by difference. This version of mestizaje could not be perceived as an active cultural project of synthesis, but rather as one that highlighted negation. ${ }^{29}$ As opposed to Australia, where there were explicit initiatives to encourage interracial mixing, in Chile, mestizaje was an extended practice from the beginning. Within this context, rather than being included, even in a limited rhetorical sense, in the nation-building project, the Mapuches have remained apart and invisible.

\section{Land, Integration and Symbols: Challenging issues}

The question of land rights, as an object of inherited dispute between the European invaders and prior custodians of the land, has meant that neither the Aborigines in Australia nor the Mapuches in Chile found reasons to celebrate within the respective bicentenaries. In Australia, the March of Freedom, Justice and Hope in Sydney, supported by the National Coalition of Aboriginal Organisations, the Redfern Group and Reverend Charles Harris, represented a

26 Manne, R. 2001, 'In denial: the Stolen Generations and the right', The Australian Quarterly Essay, no. 1, p. 2.

27 Wade, P. 2003, 'Race and nation in Latin America: an anthropological view', in N. Appelbaum, A. Macpherson and K. Rosemblatt (eds), Race and Nation in Modern Latin America, The University of North Carolina Press, Chapel Hill, p. 264.

28 Wade, P. 2005, 'Rethinking mestizaje: ideology and lived experience', Journal of Latin American Studies, vol. 37 , no. 2 , p. 245.

29 Waldman, G. 2004, 'Chile: indígenas y mestizos negados', Política y Cultura, vol. 21, [Author's translation], p. 105. 
public Aboriginal outcry for 'land rights' and 'sovereignty'. The protest was organised against what they call Invasion Day (opposition to Australia Day), also known as Survival Day, because 'if anything was to be celebrated it was 200 years of Indigenous survival'. ${ }^{30}$ Posters summarised their malaise: 'White Australia has a black history-Don't celebrate 1988.'31 The protest turned out to be the largest gathering since the arrival of the settlers and, in the long term, it demonstrated itself to be 'the most significant Bicentenary event' ${ }^{32}$ In Chile, representatives of the Mapuche people said they did not have anything to celebrate in the bicentenary. 'I am afraid (we commemorate) 128 years of occupation', historian Hernán Curiñir said while remembering the military defeat in 1881 and the later confinement of the Mapuches to small territories. ${ }^{33}$ On account of this exclusion issue and the strong feeling of defeat-clearly represented by indigenous peoples in words such as 'invasion', 'occupation' and 'survival' — neither the Mapuches nor the Aborigines had reasons to celebrate during the Chilean and the Australian bicentenaries.

Although there have been initiatives towards the restitution of traditional lands both in Australia and in Chile, further gestures in Australia as well as practical results of land transferral in Chile have been shown to be controversial and limited. Only four years after the Australian bicentenary, a decision of the High Court changed the Australian land-title laws and overthrew the notion of terra nullius ('the land of no-one'), supporting the lawsuit of Eddie Mabo and the Meriam people who claimed ownership of their ancestral land in the Torres Strait. ${ }^{34}$ Although the Mabo case represents a 'dramatic example' of 'unassailable assumptions' and precedent concerning Aboriginal land rights, the recognition of native title was 'tightly circumscribed' and the scope for more ambitious claims left unclear. ${ }^{35}$ In Chile, although the Corporación Nacional de Desarrollo Indigena (Conadi) - the official body in charge of indigenous affairs - has transferred 650 000 ha of land to the Mapuches since 1994, the indigenous communities that are recovering their territory face internal problems of distribution, understanding and communication, because both the leaders and the power structures have changed. ${ }^{36}$ The Australian bicentenary, however, came to be a platform that

\footnotetext{
30 Carter, D. 2006, Dispossession, Dreams and Diversity: Issues in Australian studies, Pearson Education, Frenchs Forest, NSW, p. 101.

31 Kwan, E. 2007, Celebrating Australia: A history of Australia Day, National Australia Day Council, Canberra, p. 12, viewed 10 October 2009, < http://www.australiaday.gov.au/pages/images/CelebratingAustralia.pdf>

32 Turner, G. 1994, Making it National: Nationalism and Australian popular culture, Allen \& Unwin, St Leonards, NSW, p. 71.

33 Cayuqueo, P. 2008, 'Sobre el bicentenario chileno tenemos mucho que decir', Enlace Mapuche Internacional, viewed 11 June 2010, <http://www.mapuche-nation.org/espanol/html/articulos/art-136.htm> [Author's translation].

34 Federal Court of Australia, 2001, The Art of Delivering Justice, Curriculum Corporation, Sydney, p. 63.

35 Ivison, D. 1997, 'Decolonizing the rule of law: Mabo's case and postcolonial constitutionalism', Oxford Journal of Legal Studies, vol. 17, no. 2, p. 272.

36 Parentini, L. 2008, 'Imaginario Mapuche', in L. Parentini and M. Rojas, Historiadores Chilenos frente al bicentenario, Comisión Bicentenario, Presidencia de la República, Santiago, [Author's translation], p. 343.
} 
introduced sensitivity to Aboriginal demands. The restitution of land has taken place within a scope of confined projections in Australia and unclear effective results in Chile especially in terms of depth and durability.

The reactions and protests originating from exclusion within the context of the Australian bicentenary sensitised the nation towards the Aborigines as a group and their claims, and opened up a path for further gestures of inclusion and reconciliation - albeit not enough to fix the notion of an inclusive nation. In Australia, the ongoing national, and at times divisive, debate on the settler/Indigenous relationship since the early 1990s has led to 'spasms of guilt, avoidance and self-justification' in the non-Indigenous population. ${ }^{37}$ Furthermore, these sentiments have had a significant influence on the development of a reconciliation movement that reached its peak in 2000 when thousands of Australians participated in walks for reconciliation in the major cities throughout the country. ${ }^{38}$ In 2008, the then Prime Minister, Kevin Rudd, delivered a government apology to the Stolen Generations. Warren Mundine, head of the Australian Indigenous Chamber of Commerce, said, however, that the apology does not mean that everything is going to be put right in Indigenous Australia: 'We all knew that was never going to happen.' ${ }^{39}$ In spite of the increased visibility of Indigenous people on account of the Australian bicentenary and these inclusive gestures at official and community levels, the discourse of the nation remains fractured.

In Chile - albeit far from reconciliation gestures and in a different context - the advent of 500 years since the arrival of the Spaniards in the Americas in 1992 became an appropriate framework for the re-emergence of the indigenous identity and its claims to be part of a transnational and global phenomenon. Bengoa points out that the first cycle understood as ethnical identity reconstruction is ending. In a new phase, the indigenous peoples are leading countries (Evo Morales in Bolivia) or running Chilean municipalities, challenging a new indigenous citizenship, where to be a national citizen and an indigenous person does not cause a contradiction. ${ }^{40}$ Three Mapuche mayors can exemplify the previous concept: Adolfo Millabur, who was elected in the locality of Tirúa (1996), and Domingo Nancupil (2000) and Ricardo Tripainao (2004), who were elected in the locality of Puerto Saavedra. This has, however, been diluted over the past years because 'the state considers that the municipalities where there is [an] absolute majority of indigenous population should be no different from

37 Moran, A. 2002, 'As Australia decolonizes: indigenizing settler nationalism and the challenges of settler/ Indigenous relations', Ethnic and Racial Studies, vol. 25, no. 6, p. 1015.

38 Ibid., p. 1018.

39 Green, S. 2011, 'Still sorry, still closing the gap', The Age, 9 February, p. 13.

40 Bengoa, J. 2009, 'Una segunda etapa de la emergencia indígena en América latina', Cuadernos de Antropología Social, no. 29, p. 7. 
those without it $^{\prime}{ }^{41}$ Despite the fact that the discourse of ethnic identity is now visible through their own indigenous leaders in positions of power, the idea that indigenous peoples are able to be indigenous only if they take part in the conditions of being a national citizen is still strong.

In spite of these inclusive issues, the integration of the cultural and ethnic diversity of the indigenous has become a controversial matter in the context of bicentenaries. In Australia, rather than highlighting the success or failures of the Aboriginal demands during the bicentenary, their demonstrations were successful in terms of elevating their rights in the national consciousness of social imperatives, projecting their efforts beyond the boundaries, and forcing nonAboriginal Australians to accept that the nature of their nation is ambiguous and contested. ${ }^{42}$ More recently, the leader of an Australian Indigenous community, Galarrwuy Yunupingu, a Gamatj man of the Yolngu people in the Northern Territory, said that the current policies of government must be adapted to conciliate 'our two worlds' ${ }^{43}$ In the context of the Chilean bicentenary, there were still pending issues in regard to the acceptance of the value of indigenous peoples within the imagined nation and its diversity. Society was interested in a rapid integration rather than in the value of their identity as a cultural asset for the nation. ${ }^{44}$ Indigenous peoples do not want to be seen, however, merely as an embellishment of national culture or an ethnic group. Both in Australia and in Chile, the integration of the indigenous population into the nation has become contentious since the acceptance of diversity clashes with the hegemonic view.

In terms of articulating the discourse of identity inclusively, neither Australia nor Chile arrived at their respective bicentenaries with an official constitutional recognition of their indigenous populations - representing a controversial matter that remains unresolved. In Ruiz's opinion, as a bicentenary is a construction that originates from power, certain strategies and discourses exclude actors such as national minorities and the indigenous people, particularly in respect of a state that fails to recognise a pre-existent diversity in its construction. ${ }^{45}$ Former Australian Prime Minister John Howard's promise in 2007 to amend the Constitution to recognise Aborigines, as well as the commitment for such acknowledgment given in 2008 by his successor, Kevin Rudd, 'remains only

\footnotetext{
41 Cayuqueo, P. 2010, 'José Bengoa y huelga mapuche: “el terrorismo siempre es y ha sido una construcción del estado"', Azkintuwe, viewed 15 February 2011, <http://www.azkintuwe.org/agost092.htm> [Author's translation].

42 Turner, Making it National, p. 87.

43 Yunupingu, G. 2010, 'We need to find ways to meet the future with hope, not on our knees', The Australian, 6 June, viewed 14 June 2010, <http://www.theaustralian.com.au/news/opinion/we-need-to-findways-to-meet-the-future-with-hope-not-on-our-knees/story-e6frg6zo-1225875425689>

44 Parentini, L. 2008, 'Imaginario Mapuche', p. 343.

45 Ruiz, C. 2008, 'Por un bicentenario sin exclusiones', in L. Parentini and M. Rojas (eds), Historiadores Chilenos frente al bicentenario, Comisión Bicentenario, Presidencia de la República, Santiago, [Author's translation], p. 432.
} 
words' ${ }^{46}$ In Chile, following a request from a group of congressmen, the government of President Sebastián Piñera decided to postpone the discussion of the indigenous peoples' constitutional recognition project to meet the requirements of the International Labour Organisation's 169 agreement. ${ }^{47}$ Furthermore, the werkén (messenger) of the Pepiukelén Mapuche community in the Región de los Lagos, Francisco Vera, said that the project has neither the support nor the approval of the indigenous communities. ${ }^{48}$ Within the context of rethinking the nation in their respective bicentenaries, neither Australia nor Chile has given formal constitutional recognition to the indigenous peoplessomething that still fractures the discourse of national identity.

The official narration of the nation also became contested within the context of the Australian and the Chilean bicentenaries in terms of multiple appropriations of symbols and meanings emanating from the official construction that clashed with the original inhabitants or placed them in a marginal or rather an invisible position. In Australia, the initial conflict of how to understand the event was represented at the level of 'possession of symbols, appropriateness of metaphors and veracity of images' ${ }^{49}$ One of the issues discussed was whether or not the First Fleet re-enactment ships should fly the Aboriginal flag and whether it was legitimate to show Uluru - a sacred site for Aborigines and known by Europeans as Ayers Rock - as an Australian representative icon within the bicentenary advertising campaign (Celebration of a Nation). Despite the fact that the original inhabitants were rhetorically visible in the Chilean bicentennial symbols such as the bicentennial song, La fuerza de la libertad (The Strength of Freedom), and one of the bicentennial stamps, they were absent from the theme, 'Celebrating What We Are' - a bicentennial poster that ignored people and diversity and metaphorically focused on the Andes Range, a geographical landmark. On account of the hegemonic official construction of bicentenaries, indigenous peoples became symbolically peripheral to the celebration.

The visibility of symbolic meanings associated with cultural identity, such as the indigenous flags both in the Australian and in the Chilean bicentenary, has been controversial, albeit in different contexts. Bengoa points out that culture becomes the only bastion for identity when independence is lost. ${ }^{50}$ In Larraín's

\footnotetext{
46 Yunupingu, 'We need to find ways to meet the future with hope'.

47 Salazar, R. 2010, 'Se retrasa proyecto de reconocimiento constitucional a pueblos indígenas', Diario Electrónico Radio Universidad de Chile, viewed 15 February 2011, <http://radio.uchile.cl/noticias/88529/> [Author's translation].

48 Radio Universidad de Chile 2011, 'Comunidad mapuche pide nuevo proyecto de reconocimiento constitucional a pueblos originarios', Diario Electrónico, viewed 4 April 2011, <http://radio.uchile.cl/ noticias/88529/>

49 Cochrane, P. and Goodman, D. 1992, 'The great Australian journey: cultural logic and nationalism in the postmodern era', in T. Bennett, P. Buckridge, D. Carter and C. Mercer (eds), Celebrating the Nation: A critical study of Australia's bicentenary, Allen \& Unwin, St Leonards, NSW, p. 25.

50 Bengoa, Historia del pueblo Mapuche, p. 370.
} 
perspective, identity is not only a question of cultural similarities, but also a matter of possessions and objects that can affect self-recognition and give a sense of belonging to a desired community. ${ }^{51}$ In Australia, the Aboriginal flagassociated with land rights - became the symbol in defiance of the bicentenary and the British occupation of land. More recently, it has been hoisted during public events such as the march for reconciliation in 2000, National Reconciliation Week in May and the anniversary in the Eddie Mabo case in June. One of the most controversial gestures took place when the sprinter Cathy Freeman defied the organisation of the 1994 Commonwealth Games in Canada and waved both the Aboriginal flag and the national Australian flag during her victory lap. ${ }^{52}$ The day prior to the Chilean bicentenary, a group from a movement called 'Equality' unfurled a Mapuche flag in opposition to the Chilean one in front of the government palace, albeit without hoisting it. During the Chilean bicentennial year, the Mayor of the city of Villarrica-Mapuche territory in the nineteenth century - authorised the hoisting of the Mapuche flag in front of the town hall on the occasion of the Indigenous Peoples Day, in June 2010. ${ }^{53}$ The General Controller of the Republic said that the Mapuche flag may be hoisted adjacent to the national flag in town halls if those symbols represent a 'cultural, educational or artistic expression of the referred ethnicity'. ${ }^{54}$ The visibility of both the Aboriginal and the Mapuche flags - as symbols associated with cultural identity and land rights - becomes contentious in terms of equal representation of indigenous peoples who protest against the hegemonic construction of a national celebration and where the sense of belonging to the nation becomes very questionable.

\section{Conclusions}

As discussed above, modern society has not resolved its relationship with indigenous peoples. In the context of bicentenaries, as chosen historic moments, rethinking the nation becomes a useful exercise in understanding how the narration of identity emerges in terms of representation in the imagined community. Nowadays this representation is fractured on account of exclusion issues emanating from the colonial project of imagining the nation as a 'white' construction. The sudden emergence of Aboriginal claims during the Australian bicentenary and the reappropriation of an indigenous identity in the context

\footnotetext{
51 Larraín, Identity and Modernity in Latin America, p. 25.

52 Australia On Net 2007, 'Cathy Freeman', Australia On Net, viewed 19 July 2010, <http://www. australiaonnet.com/about-australia/famous-australians/cathy-freeman.html>

53 Fredes, I. 2010, 'Izan bandera mapuche frente al edificio del municipio de Villarrica', El Mercurio, 25 June, p. C7, [Author's translation].

54 Mendoza, R. 2010, ID Dictamen: 022247N10, Contraloría General de la República, viewed 19 July 2010, $<$ http://www.contraloria.cl/LegisJuri/DictamenesGeneralesMunicipales.nsf/DetalleDictamen?OpenForm\&U NID=6C38E0508439B0B98425771500584699 > [Author's translation].
} 
of the Chilean bicentenary as part of the opposition against the five-hundredth anniversary of the arrival of Spaniards in the Americas can both be regarded as transnational phenomena that clash with the dominant discourse of the nation as they try to find new spaces within society.

The idea of representing two worlds in one nation, which followed the words of the Australian Indigenous community leader Galarrwuy Yunupingu, becomes contentious on account of inherited divisions that have fragmented the discourse of the nation. While the official reconstruction of the nation within the Australian and the Chilean bicentenaries tried to articulate a message of community, the indigenous discourse represented the gap between the invaders and the invaded and challenged the discourse of the nation.

The historical consequences of the foundational moment in terms of winners and defeated peoples both in Australia and in Chile have created a negative articulation within the idea of an imagined community. Land, as an object of appropriation and further disputation, as well as the imposition of the colonisation project carried out by conquistadors and settlers, established a complex relationship, whereby indigenous peoples became peripheral to the hegemonic project. Therefore, far from perceiving bicentenaries as a moment of celebration, indigenous peoples both in Australia and in Chile instead felt marginalised, leading them to protest or rather express their idea of selfrecognition through symbols, such as the indigenous flag.

In a certain way, the Australian bicentenary became the starting point towards a collective awareness of Indigenous peoples, as Australians adopted further gestures of inclusion in the years that followed. Within the context of the Chilean bicentenary, however, it might be too soon to evaluate whether or not this chosen moment represented a change of collective attitude towards the Mapuches in terms of visibility. Perhaps this commemoration will not alter the image of indigenous peoples in a society with unresolved cultural tensions in terms of race, class and power. The nation is and will be an unfinished project that should demonstrate its capacity for providing cohesion to its members in a new context. The question that will likely be asked is how much of a change the nation will be able to demonstrate towards inclusion in the next tercentenary. 